\title{
Alobar holoprosencephaly
}

INSERM

\section{Source}

INSERM. (1999). Orphanet: an online rare disease and orphan drug data base. Alobar holoprosencephaly. ORPHA:93925

Alobar holoprosencephaly is the most severe classical form of holoprosencephaly (HPE; see this term) characterized by a single brain ventricle and no interhemispheric fissure. 